\title{
Adedapo Adewunmi Oluwatayo \\ Criteria for architect selection and satisfaction among first-time private sector clients
}

\begin{abstract}
For sustained profitability, architects must position themselves to attract new clients. This involves understanding potential clients' choices and how these might impact on subsequent satisfaction. The study ranked criteria for architect selection and how these predict satisfaction among first-time private sector clients in Lagos, Nigeria. Data from a questionnaire survey were analysed using descriptive statistics, relative importance index and categorical regression, identifying timely delivery, cost of service and quality of previous services as the most important criteria. Although personal relationship has been said to influence selection of a professional service provider, this criterion was found to be of relatively low importance here. To attract private sector clients, architects should prioritise improved service delivery and construction skill development.
\end{abstract}

Keywords: architectural service, first-time client, private sector client, Nigeria, selection criteria, service provider selection

\section{Introduction}

To position themselves to compete effectively and attract customers, businesses must understand customer choices. In the relationship between service provider and client, selection of the right provider is a crucial first step, determining value and satisfaction for the client and new customer acquisition for the provider. In professional service circles, customers are often referred to as 'clients'; according to Bailey (2000), a client procures professional services while a customer buys goods and services. This is a pertinent distinction for professional services such as architecture, especially in the light of the increasing failure of firms due to their inability to attract more jobs from prospective clients as noted by Pearson, Egan and Nakazawa (2003) and Larsen (2005).

Architects provide services for both public and private sector clients. In the public sector (which includes government agencies and different tiers of government), there are often well-defined criteria for the selection of service providers, and the process is often managed by persons working in related fields As indicated by researchers such as Sporrong (2011), Mathonsi and Thwala (2012) and Rönn (2014), this can make it easier for architects to position themselves to target public sector projects.

In contrast, potential private sector clients may include individuals, families or privately run organisations, and services are often heterogeneous because they are tailored to client needs (Kugyte \& Sliburyte, 2005). Additionally, private sector clients may not have written criteria for selecting service providers, and Kugyte and Sliburyte (2005) note that selection may be based on subjective attributes. Anecdotal evidence also suggests that for first-time private sector clients, information on architectural services providers or the services they provide may be inadequate, not least because some of the services that architecture delivers are not tangible.

For present purposes, the term first-time private client is used to refer to someone engaging the services of an architect for the first time. Such clients may lack adequate knowledge of statutory requirements, of which service provider would best meet their needs or of what architectural services entail, and it is the architect's responsibility to educate these 
clients. Duhan, Johnson, Wilcox and Harrell (1997) suggested that clients may often seek recommendations from family and friends, selecting service providers they like or feel they can trust (Demkin, 2008) - in other words, the choice of architect may be influenced by personal relationships. In addition, first-time private sector clients are often unsure what they want and will often rely on the architect to define the problem before proposing an architectural solution. For this reason, the choice of architect is very important, as it is likely to affect the service outcome and, ultimately, client satisfaction with services rendered. Clients in this category therefore create an interesting scenario precisely because of their lack of knowledge about what engaging an architect entails. Additionally, they may be unable to assess architectural services before paying because of the simultaneity of production and consumption. As alternatives are not easily identifiable, it may be difficult to make comparisons, especially for first-time clients. In turn, the architect may know little about how best to satisfy such clients, who are crucial as a potential source of new business.

The criteria applied in the selection of professional services providers have been discussed by a number of authors, including Araloyin and Olatoye (2011), Razzouk, Seitz and Webb (2004) and Cheung, Kuen and Skitmore (2002). Based on a synthesis of previous studies in the accounting, automobile insurance, commercial banking, mortgage banking, copy services, medical, architectural and engineering services sectors, Kugyte and Sliburyte (2005) concluded that these criteria are likely to vary according to both service type and client type. It is therefore reasonable to expect variation in the importance assigned to selection criteria, but very little is known about the ranking of such criteria among architecture services clients, or about how this influences satisfaction.

Nigeria provides an appropriate setting for exploration of this issue in light of Vision 20:2020, whose objectives include infrastructural development. Strategies to achieve this objective include the provision of affordable and accessible housing, and new layouts are being opened to encourage the private sector to participate in this drive. This government effort reflects the fact that the middle class in Nigeria has expanded (Standard Bank, 2014), leading to further development of the construction industry, as demand for housing has also gradually increased. Since 2008, the contribution of the construction industry to Nigeria's Gross Domestic Product has been more than 3\% (Waziri \& Bala, 2014).

In particular, Lagos provides an interesting context for this study. First, as the country's commercial centre, Lagos is highly urbanised; the property market has grown substantially, and several informal settlements have emerged to provide shelter for the influx of people and businesses (Opoko, 2013). In addition, Lagos State has designated nine model cities: Ajara Action Area, Otto, Meiran-Amikanle, Ikorodu-Epe, Apapa, Agege-Ifako Ijaiye, Mainland, Badadry, Lekki and Ikoyi-Victoria Island (Capital, 2010). The Lekki Free Trade Zone is another element in the drive for infrastructural development.

Lagos is also of interest in the present context because most of the architectural firms registered to practice in Nigeria (213 of a total 613) are located in various parts of the city (Architects Registration Council of Nigeria, 2010). The clients of those firms are the subjects of this study. The objective of the study is to assess the criteria used by first-time private sector clients in selecting an architectural services provider and how the satisfaction of the clients is determined by these selection criteria. To that end, the study addresses the following four questions. 1) What are the principal criteria used by first-time private sector clients in selecting an architect? 2) How do these criteria vary according to service requirement? 3) How do these criteria vary according to building type? 4) Which of these selection criteria are good predictors of client satisfaction with services provided? By ranking the criteria that firsttime private sector clients use in deciding which architect to engage, the present study will help architects to position themselves, using appropriate marketing strategies to expand their 
client base. From the client's perspective, empirical data on these criteria will help to ensure better service satisfaction.

\section{Literature Review}

The search for a service provider can broadly be described in terms of three key criteria: search, experience and credence. While search criteria (which include pricing, convenience and previous projects) can readily be evaluated prior to selection, Kugyte and Sliburyte (2005) noted that experience (core services and service encounter) and credence (encompassing reputation and brand name familiarity) may be less easily evaluated until the service has been rendered. These attributes were derived from a synthesis of findings regarding the selection of service providers from fields categorized as service shops, professional services and generic (mass) services.

According to Chappell and Willis (2000), the services provided by architects may range from design to administration of construction projects. It might therefore be expected that the criteria adopted by first-time private sector clients would vary with the type of service required. The American Institute of Architects (AIA) (Demkin, 2008) identified three general criteria for selection of an architect: value, cost and qualifications. However, these apply only when the direct hire option is not used. Qualifications-based selection (QBS), used mostly in the public sector and by multiple-project clients, has been widely studied (e.g. Sporrong, 2011). This approach is based on criteria that include the architect's competence, experience and reputation, related to Kugyte and Sliburyte's (2005) credence and pre-purchase knowledge, suggesting that QBS assigns less importance to relational selection criteria. The QBS has been criticised for tendency to hinder new firms from being selected.

Value-based selection, said to be popular among inexperienced clients, is based on criteria such as the architect's capacity to produce innovative solutions and their commitment to the client's interest. Cost-based selection, based mainly on cost efficiency, is thought to be most popular among private sector clients. It has been suggested that clients who emphasise value tend to focus less on cost as a selection criterion, and vice versa. However, Bayazit and Karpak (2013) are among those who posit that this process is often based on multiple criteria. While the criteria for rating alternative providers have been investigated in the context of the decision-making process, less is known about the relative importance of these multiple criteria. The present study addresses this knowledge gap.

Criteria used in the selection of professional service firms are known to include reputation (Scott \& Watt, 1995; Almossawi, 2001; Razzouk, Seitz \& Webb, 2004; Araloyin \& Olatoye, 2011) and interpersonal skills (Razzouk, Seitz \& Webb, 2004); some of these criteria have also been identified in the selection of architects. For example, Day and Barksdale's (2003) qualitative study identified three broad criteria used by clients in selecting architectural and engineering services providers: core services, service encounter and reputation. The core services criterion relates to service providers' perceived understanding of client requirements, as well as experience, expertise and competence. The service encounter criterion relates to service providers' perceived relationship and communication skills. Finally, the reputation criterion assesses the likelihood that the service provider will conform to contractual agreements, based on track record as accessed through previous projects or clients. Cheung, Kuen and Skitmore (2002) found that real estate developers in Hong Kong also place emphasis on professional qualifications and consultancy fees as criteria for selecting architects. Their findings differ from previous studies in that reputation rated low as a selection criterion, and criteria were found to vary according to services required.

Focused on limited competitions in Sweden, Rönn (2014) found that selection criteria included quality of design, innovative solutions to architectural problems, collaboration with client/contractor, professional competence and resources, as well as the architect's reputation. 
However, it should be noted that, in such competitions, the call for entries often comes through architectural associations (as in Rönn's study) or is confined to a few reputable firms. Designs and company profiles are submitted prior to selection, enabling a choice to be made on the basis of design quality and the profile of the architect or firm. In contrast, individual clients may not have access to an architectural association in sourcing an architect, and the process of organising competitions may be unduly resource-intensive, as assessors must be engaged and paid. For this reason, these clients are likely to opt for direct hire, often based on the recommendation of a friend, another client or another architect who has had a professional or personal relationship with the architect, or sometimes on the architect's wider reputation.

As mentioned earlier, it can be difficult to evaluate services before purchase in the context of a professional service like architecture. As a result of this characteristic of services, which has been described as intangibility (Kindström, Kowalkowski \& Nordin, 2012), Kugyte and Sliburyte, (2005) noted that clients seeking information on professional service providers often rely on personal information or referral (see also Chappell \& Willis, 2000). This is partly a result of the personalized nature of services provided and the no-advertising rule that governs most professional services. Kugyte and Sliburyte (2005) therefore suggested that reputation would play a greater role than price in the selection of professional service providers, in contrast to other areas where services can be evaluated prior to purchase, the consequences of failure are minimal (given the possibility of a refund or redo) and comparison of products is possible. In addition, unlike fields where price is of greater importance, Kugyte and Sliburyte (2005) suggested that the assessment of architects' referral information may be subjective. This presupposes that price is not important in the selection of professional services, although this assumption requires further investigation.

Selection of a service provider is often based on client service expectations, and this may determine subsequent client satisfaction. As defined by Masrom and Skitmore (2010), satisfaction is determined by whether a product or service meets the customer's aspirations or expectations. When a client selects an architect, it is in the hope that the required services will be satisfactorily provided; in many cases, then, the client's focus determines whether the right service provider has been selected. Building on previous research, the present study investigates the criteria used by private sector clients in selecting an architect that they have never commissioned before, and how these criteria relate to subsequent client satisfaction.

\section{Research Methods}

To recruit participants for the study, architectural firms registered to practice in Nigeria (ARCON, 2010) were first contacted to obtain their consent to access a list of their clients for the previous two years. Fifty-seven firms agreed to participate in the survey, each providing a list of five clients; to allow for non-responses, four clients were then randomly selected from each list. Where the number of clients was less than four, all the firm's clients were selected. These clients were then contacted to obtain their consent for participation. In total, 228 clients agreed to participate in the study.

A questionnaire was developed for the purpose of data collection, with the help of ten potential clients to ensure that the issues investigated were of relevance to the target population. The questionnaire was pre-tested and fine-tuned to ensure its validity and the clarity of questions. The aim was to ensure standardised questions, allowing responses to be compared. Client judgments of the importance of criteria for architect selection were measured on a 5 -point scale (from $1=$ not important at all to $5=$ very important). Cronbach's alpha testing confirmed the scale's reliability (Cronbach's alpha $=0.734)$ (George \& Mallery, 2003). Satisfaction was measured using a single scale. In line with Mbachu and Nkedo (2007), respondents were asked to indicate on a scale of 1 to 5 how satisfied they were with services received, from 1 (not satisfied at all) to 5 (very satisfied). 
In total, 196 questionnaires were returned, representing a response rate of $86 \%$. Criteria were assessed using the relative importance index (RII), measured as $\mathrm{RII}=\sum \mathrm{W} / \mathrm{H} * \mathrm{~N}$, where $\mathrm{W}$ is the weight attached to criteria by respondents, $\mathrm{H}$ is the highest weight for each criterion (in this case, 5) and $\mathrm{N}$ is the number of respondents. A categorical regression was performed to determine which selection criteria significantly predicted satisfaction among first-time private sector clients.

\section{Results}

The results indicate that $31.6 \%$ of these first-time clients engaged architects solely for design services (Table 1). However, a higher percentage (51\%) engaged architects for design and construction projects, and just $9.7 \%$ of engaged architects for renovation or interior design services. This suggests that most of the services provided by these architects in Lagos related to design or design and construction (otherwise known as design-build). This confirms the earlier findings of Oluwatayo (2009), although an increase was observed in design-build services. In the present study, the least procured service was project management $(2.0 \%)$, followed by construction-only services $(5.6 \%)$. This result is interesting, as it suggests that architects are also being contracted to provide construction services. However, further investigation showed that some of these architects were registered as consortiums involving other construction professionals, enabling them to handle construction services.

Table 1. Project profiles.

\begin{tabular}{lll}
\hline Measures & Items & $(\%)$ \\
\hline Type of service & Design & 31.6 \\
& Construction & 5.6 \\
& Design and construction & 51.0 \\
& Project management & 2.0 \\
& Renovation/ interior design & 9.7 \\
\hline Building type & Residential & 64.8 \\
& Office & 11.2 \\
& Educational & 12.8 \\
& Religious & 3.6 \\
& Industrial & 3.6 \\
& Healthcare & 1.5 \\
& Entertainment & 1.0 \\
\hline Client satisfaction with service & Not satisfied at all & 1.7 \\
& Undecided & 12.8 \\
& Satisfied & 66.1 \\
& Very satisfied & 19.4 \\
\hline
\end{tabular}

Most of these first-time private clients (65.8\%) engaged an architect for residential projects, which may reflect the increased drive for home ownership accompanying the expansion of the middle class. Few clients engaged the architect for educational $(13 \%)$ or office projects $(11.4 \%)$, and still fewer for industrial (3.6\%), religious $(3.6 \%)$, healthcare $(1.6 \%)$ or entertainment projects (1\%). Most of those clients who sought services for residential projects procured either design-only or design and construction services. It is interesting to note that none of the clients who engaged architects for religious, industrial and healthcare projects procured design-only services; these building types are often specialised and require the involvement of more than one professional, even at the design stage. Table 1 also shows that 
most respondents were satisfied $(66.1 \%)$ or very satisfied $(19.4 \%)$ with the services they received from their chosen architect; very few (1.7\%) were not satisfied at all. A closer look at the data shows that all those who were not satisfied with the services they received had procured design and construction services for residential projects. The reason for this finding is not immediately clear; some clients suggested that design and construction services are often flawed, with cost overruns, but this needs to be further investigated.

To answer the first research question, the relative importance index was used in establishing the relative importance of the criteria investigated in the study. The relative importance index (RII) ranged from 1 to 5 (where $1=$ completely irrelevant and $5=$ very relevant). The results in Table 2 reveal that the most important criterion for first-time private sector clients when selecting their architect is timely delivery $(\mathrm{RII}=0.883)$, followed by cost of service $(\mathrm{RII}=0.845)$ and quality of previous projects $(\mathrm{RII}=0.844)$. The least important criteria are personal relationship and the gender and religion of the architect. These results suggest that the core service and reputation components identified by Day and Barkdale (2003) were more highly ranked than the service encounter selection component. It would therefore appear that service expectation may be more important to the client than existing relationships when selecting an architectural services provider.

This result appears to conflict with Kugyte and Sliburyte's (2005) assertion that reputation would play a stronger role than cost in the selection of a professional service provider. However, it supports the finding of Cheung, Kuen and Skitmore (2002) that consultancy fee ranked higher than reputation in the selection of architects by real estate firms. As shown in Table 3, this was also the case when type of service procured was considered. These findings also align with previous studies in that cost efficiency is identified as a criterion for architect selection in the context of private sector clients, as in Sporrong (2011). The overall ranking of criteria also shows that reputation ranked higher that competence and experience of the architect for these clients. This conflicts with the findings of Cheung, Kuen and Skitmore (2002) and Rönn (2014), who found that professional competence and experience ranked higher than reputation in the selection of architects by real estate firms and organisers of public sector limited competitions. However, relative to competence, the importance of reputation as an selection criterion appears to be a function of service type.

Table 2. Relative importance of criteria used by first-time private sector clients in selecting architects.

\begin{tabular}{lcc}
\hline & RII & Rank \\
\hline Timely delivery & 0.883 & 1 \\
Cost of service & 0.845 & 2 \\
Quality of previous projects & 0.844 & 3 \\
Reputation in specific area of need & 0.794 & 4 \\
Competence in particular project area & 0.790 & 5 \\
Experience in the industry & 0.780 & 6 \\
Capacity for innovation & 0.749 & 7 \\
Variety of services offered & 0.723 & 8 \\
Personal relationship & 0.676 & 9 \\
Gender & 0.523 & 10 \\
Religion & 0.492 & 11 \\
\hline
\end{tabular}


Table 3 (on page 8) shows that reputation ranks higher than competence only for project management, interior design and renovation services. The RII reveals further significant differences in the ranking of selection criteria by type of service procured. Although timely delivery ranks as the most important selection criterion when considering all services together, it was of only moderate importance when each services is considered separately, ranking sixth or eighth. On the other hand, quality and cost were highly ranked, irrespective of the type of service. It is also interesting to note that religion, which ranked least important overall, was highly important to clients seeking project management services. This may suggest the place of perceived religious affinity for this type of service, which may entail that the architect taking control of an entire project from conception to actualisation, on behalf of the client. A further look at the data however revealed that the clients that sought project management services sought this for religious and entertainment buildings. It therefore appears that the importance of religion as architect selection criterion is a reflection of the building type. This needs to be further investigated. Gender was also an important consideration for clients who selected architects for project management services.

Another interesting result was that personal relationship with the architect was of only moderate importance when the client sought design-only and project management services, contrary to earlier findings such as those of Duhan et al. (1997). This suggests that clients are more objective in their assessment when an architect is required to provide architectural services. Sporrong's (2011) suggestion that clients who emphasize cost tend to place less emphasis on value is confirmed overall, as shown in Table 2. While capacity for innovation was ranked very low, cost was ranked as more important, but this was not an absolute rule when considering specific services (Table 3). For design services, cost was ranked first while innovation was ranked eighth. Similar trends were observed for design and construction, project management, renovation and interior design, where cost ranked first or second and capacity for innovation ranked sixth. For construction services, however, the rankings were close, with both criteria highly ranked. Innovation in construction has been identified as one of the ways of saving cost (Demkin, 2008), and it would appear that these clients are aware of this, selecting their architect on the basis of their ability to achieve cost-efficiency through innovation during construction.

Again, the importance of cost relative to capacity for innovation was not a one-way ranking when considering project type. While cost of service was a stronger consideration than innovation for clients seeking architectural services for residential, educational, office or entertainment projects, capacity for innovation was more important for clients seeking services for religious and industrial buildings. This is clear from the RII results for ranking of selection criteria across different project types, as shown in Table 4. These results also show that the most important overall criterion (timely delivery) was also most important for all except religious and industrial projects. Similarly, cost - the second most important criterion overall -was less important for clients seeking architectural services for religious and industrial projects, coming behind other considerations like timely delivery, quality of previous work, personal relationship and competence in particular project areas in the case of office projects. The importance of cost relative to reputation of service provider also varied with project type. As suggested by Kugyte and Sliburyte (2005), reputation played a greater role than price for religious and industrial projects. However, cost was more important than reputation for residential and entertainment projects. Religion, which ranked lowest overall, was understandably a more important consideration than cost and personal relationship in the selection of architects for religious buildings. Surprisingly, however, it was also more important than gender and capacity for innovation for entertainment projects, and there is again a need for further investigation of this finding. 
Table 3. Ranking of architect selection criteria by type of service procured.

\begin{tabular}{|c|c|c|c|c|c|c|c|c|c|c|}
\hline & \multicolumn{2}{|c|}{ Design } & \multicolumn{2}{|c|}{ Construction } & \multicolumn{2}{|c|}{$\begin{array}{c}\text { Design } \\
\text { and Construction }\end{array}$} & \multicolumn{2}{|c|}{$\begin{array}{c}\text { Project } \\
\text { Management }\end{array}$} & \multicolumn{2}{|c|}{$\begin{array}{l}\text { Renovation/Inte } \\
\text { rior design }\end{array}$} \\
\hline & $R / I$ & Rank & $R / I$ & Rank & $R / I$ & Rank & $R / I$ & Rank & $R / I$ & Rank \\
\hline Timely delivery & .739 & 6 & .636 & 8 & .618 & 8 & .8 & 6 & .768 & 8 \\
\hline Cost of service & .855 & 1 & .927 & 3 & .804 & 2 & 1.0 & 1 & .937 & 2 \\
\hline Quality of previous projects & .8 & 2 & .818 & 5 & .838 & 1 & 1.0 & 1 & 1.0 & 1 \\
\hline $\begin{array}{l}\text { Reputation in specific area of } \\
\text { need }\end{array}$ & .755 & 4 & .8 & 6 & .788 & 4 & 1.0 & 1 & .905 & 3 \\
\hline $\begin{array}{l}\text { Competence in particular project } \\
\text { area }\end{array}$ & .757 & 3 & 1.0 & 1 & .794 & 3 & 6 & 11 & .789 & 7 \\
\hline Experience in the industry & .755 & 4 & .945 & 2 & .754 & 5 & 1.0 & 1 & .895 & 4 \\
\hline Capacity for innovation & .716 & 8 & .855 & 4 & .742 & 6 & .8 & 6 & .84 & 6 \\
\hline Variety of services offered & .658 & 9 & .8 & 6 & .726 & 7 & .8 & 6 & .863 & 5 \\
\hline Personal relationship & .739 & 6 & .636 & 8 & .618 & 8 & .8 & 6 & .768 & 8 \\
\hline Gender & .523 & 10 & .418 & 11 & .506 & 10 & .8 & 6 & .611 & 11 \\
\hline Religion & .494 & 11 & .491 & 10 & .412 & 11 & 1.0 & 1 & .8 & 10 \\
\hline
\end{tabular}

Table 4. Ranking of architect selection criteria by type of project.

\begin{tabular}{|c|c|c|c|c|c|c|c|c|c|c|c|c|c|c|}
\hline & \multicolumn{2}{|c|}{ Residential } & \multicolumn{2}{|c|}{ Office } & \multicolumn{2}{|c|}{ Educational } & \multicolumn{2}{|c|}{ Religious } & \multicolumn{2}{|c|}{ Industrial } & \multicolumn{2}{|c|}{ Healthcare } & \multicolumn{2}{|c|}{ Entertainment } \\
\hline & $R I I$ & Rank & $R I I$ & Rank & $R I I$ & Rank & $R / I$ & Rank & $R I I$ & Rank & $R / I$ & Rank & $R / I$ & Rank \\
\hline $\begin{array}{l}\text { Ability for timely } \\
\text { delivery }\end{array}$ & .888 & 1 & .873 & 1 & .944 & 1 & .714 & 7 & .886 & 4 & .8 & 1 & 1.0 & 1 \\
\hline Cost of service & .848 & 2 & .8 & 5 & .928 & 2 & .629 & 11 & .743 & 8 & .8 & 1 & 1.0 & 1 \\
\hline $\begin{array}{l}\text { Quality of } \\
\text { previous } \\
\text { projects }\end{array}$ & .839 & 3 & .845 & 2 & .824 & 5 & .886 & 2 & 1.0 & 1 & .8 & 1 & .8 & 4 \\
\hline $\begin{array}{l}\text { Reputation in my } \\
\text { specific area of } \\
\text { need }\end{array}$ & .776 & 4 & .745 & 7 & .88 & 3 & .8 & 3 & 1.0 & 1 & .8 & 1 & .6 & 5 \\
\hline $\begin{array}{l}\text { Competence in } \\
\text { particular project } \\
\text { area }\end{array}$ & .771 & 5 & .809 & 4 & .832 & 4 & .771 & 5 & .771 & 7 & .8 & 1 & 1.0 & 1 \\
\hline $\begin{array}{l}\text { Experience in } \\
\text { the industry }\end{array}$ & .767 & 6 & .745 & 7 & .8 & 6 & .9 & 1 & 1.0 & 1 & .8 & 1 & .6 & 5 \\
\hline $\begin{array}{l}\text { Capacity for } \\
\text { innovation }\end{array}$ & .738 & 7 & .736 & 9 & .784 & 7 & .771 & 5 & .886 & 4 & .8 & 1 & .4 & 10 \\
\hline $\begin{array}{l}\text { Variety of } \\
\text { services offered }\end{array}$ & .720 & 8 & .736 & 9 & .656 & 8 & .8 & 3 & .886 & 4 & .8 & 1 & .6 & 5 \\
\hline $\begin{array}{l}\text { Personal } \\
\text { relationship }\end{array}$ & .702 & 9 & .827 & 3 & .488 & 9 & .686 & 10 & .523 & 11 & .8 & 1 & .6 & 5 \\
\hline Gender & .491 & 10 & .755 & 6 & .472 & 10 & .714 & 7 & .543 & 10 & .6 & 10 & .2 & 11 \\
\hline Religion & .491 & 10 & .6 & 11 & .304 & 11 & .714 & 7 & .657 & 9 & .6 & 11 & .6 & 5 \\
\hline
\end{tabular}

Selection of a service provider has been linked to client satisfaction, and in selecting an architect, the criteria adopted by first-time private sector clients are based on expectations in terms of services rendered. A categorical regression analysis was therefore performed to identify which selection criteria significantly predict client satisfaction. Client perception of satisfaction (on an ordinal scale) was entered as the dependent variable while the selection criteria were entered as independent variables. The results show that four of the criteria predict satisfaction among first-time private sector clients $\left(F=6.49, \mathrm{R}^{2}=0.613, \mathrm{p}=0.00\right)$. As shown in Table 5, these include cost of service (Beta $=-0.35, \mathrm{~F}=6.32, \mathrm{p}=0.002)$ and reputation of the architect in the area of need (Beta $=0.49, F=4.25, p=0.041)$. Other predictors include quality of previous projects $($ Beta $=-0.22, F=3.20, p=0.044)$ and personal relationship with the architect $($ Beta $=-0.296, \mathrm{~F}=6.68, \mathrm{p}=0.00)$. 
Table 5. Architect selection factors predicting satisfaction among first-time private sector clients.

\begin{tabular}{|c|c|c|c|c|c|}
\hline \multicolumn{6}{|c|}{ Coefficients } \\
\hline & \multicolumn{2}{|c|}{ Standardized Coefficients } & df & $\mathrm{F}$ & Sig. \\
\hline & Beta & $\begin{array}{l}\text { Bootstrap } \\
(1000) \\
\text { Estimate of } \\
\text { Std. Error }\end{array}$ & & & \\
\hline Experience in the industry & .249 & .179 & 2 & 1.927 & .149 \\
\hline Cost of service & -.353 & .140 & 2 & 6.320 & .002 \\
\hline $\begin{array}{l}\text { Reputation in specific } \\
\text { area of need }\end{array}$ & .494 & .240 & 1 & 4.252 & .041 \\
\hline Capacity for innovation & -.554 & .344 & 2 & 2.598 & .078 \\
\hline $\begin{array}{l}\text { Quality of previous } \\
\text { projects }\end{array}$ & .220 & .123 & 2 & 3.196 & .044 \\
\hline Variety of services offered & .394 & .281 & 2 & 1.970 & .143 \\
\hline $\begin{array}{l}\text { Competence in particular } \\
\text { project area }\end{array}$ & .105 & .105 & 3 & 1.000 & .395 \\
\hline Personal relationship & .296 & .115 & 3 & 6.675 & .000 \\
\hline Timely delivery & .158 & .105 & 2 & 2.262 & .108 \\
\hline Gender & -.463 & .239 & 2 & 3.753 & .026 \\
\hline Religion & .449 & .129 & 2 & 12.198 & .000 \\
\hline
\end{tabular}

The results further indicate that respondents who assigned high importance to the cost of services recorded lower satisfaction with services obtained, and those who rated cost of service as of lower importance recorded higher satisfaction with services. Higher rating of architect reputation in the client's area of interest, quality of previous service and personal relationship with the architect were associated with higher satisfaction with services. Another interesting result is the level of importance assigned to religion as a selection criterion, as both gender and religion also predicted satisfaction among these clients. However, while a greater emphasis on gender was linked to lower satisfaction, a greater emphasis on religion was linked to higher satisfaction. Again, this finding requires further investigation.

\section{Conclusion}

Although the public sector has been investigated in more detail, there has been little empirical work to date on the criteria used by first-time private sector clients in selecting an architect, and these clients constitute most of the new business of architecture firms. The present study contributes to the literature by providing empirical evidence of the relative importance assigned to a number of the criteria used by first-time private sector clients, and by identifying those criteria that predict client satisfaction. These findings will help architects to position themselves to attract new clients, boosting their client base and, ultimately, their profitability. Although previous studies have highlighted the importance of personal relationships in the selection of a professional service provider, the present results suggest that other criteria are more important for first-time private sector clients in selecting an architect, including timely delivery, quality of service and reputation. One implication of these findings is that architects 
need to improve their skills and services, given the importance assigned to core service criteria such as competence, quality of previous projects and experience, as well as architect's reputation. The fact that the reputation of the architect ranked higher than competence and experience - and higher even than cost for most services and project types - also suggests that architects need to build a better reputation in order to enhance their prospects of securing work from first-time private sector clients.

Although the importance of personal relationships varies with the type of service and project, this is clearly a key factor in that it predicts client satisfaction, and architects' education may need to include further development of interpersonal skills. In addition, the fact that about half of these respondents procured design and construction services suggests that architects' education should include more construction-related content - all the more so because clients who were not satisfied at all with the services they received were those who had procured design and construction services, suggesting inadequacies in the provision of this type of service. The professional body might also consolidate architects' education by offering short courses in this area. In general, these findings suggest that some areas need further study, including the observed dissatisfaction in relation to design and construction services, and how and why religion is used as a criterion for selection of architects by firsttime private sector clients seeking project management services.

Granted its contribution to knowledge, the study has a number of limitations. First, only the private sector has been investigated, and future studies might usefully compare public and private sector clients to elicit variations in the importance assigned to various criteria for architect selection. Second, data were collected only from first-time clients, who may have little or no experience in working with architects; more experienced clients may employ additional criteria, such as previous experience with the client, which were not investigated here. Third, the quantitative approach used in this study might be complemented by qualitative methods to elicit criteria that may not have been investigated here. Finally, this study covered only architectural firms based in Lagos, and further studies should investigate other locations in order to determine the extent to which these findings might be generalised.

\author{
Dr. Adedapo Adewunmi Oluwatayo \\ Lecturer, Department of Architecture, \\ Covenant University, Ota, Ogun State, Nigeria \\ Email address: dapo.oluwatayo@covenantuniversity.edu.ng
}




\section{References}

Almossawi, M. (2001). Bank selection criteria employed by college students in Bahrain: An empirical analysis. International Journal of Bank Marketing, 19(3), 115-125.

Araloyin, F. M. \& Olatoye, O. (2011). Factors influencing the selection of real estate agents in Lagos Metropolis, Nigeria. British Journal of Management \& Economics, 1(1), 33-41.

Architects Registration Council of Nigeria (ARCON). (2010). Register of Architectural Firms Entitled to Practice in the Federal Republic of Nigeria.

Bailey, J. J. (2000). Students as clients in a professional/client relationship. Journal of Management Education, 24(1), 353-365.

Capital, A. (2010). How effective are Lagos' model city plans? Retrieved 1 October, 2015, from http://www.howwemadeitinafrica.com/how-effective-are-lagos-model-city-plans/5482/

Cheung, F. K. T., Kuen, J. L. F. \& Skitmore, R. M. (2002). Multi-criteria evaluation model for the selection of architectural consultants. Construction Management and Economics, 20(7), 569-580.

Day, E. \& Barksdale, H. C. (2003). Selecting a professional service provider from the short list. Journal of Business \& Industrial Marketing, 18(6/7), 564-579.

Demkin, J. A. (Ed.). (2008). The Architect's Handbook of Professional Practice (14 ${ }^{\text {th }}$ ed.). USA: Wiley.

Duhan, D. F., Johnson, S. D., Wilcox, J. B. \& Harrell, G. D. (1997). Influences on consumer use of word-ofmouth recommendation sources. Journal of the Academy of Marketing Science, 25(4), 283-295.

George, D. \& Mallery, P. (2003). SPSS for Windows step by step: A simple guide and reference. 11.0 Update (4th ed.). Boston, MA: Allyn \& Bacon.

Holt, G. D. (2010). Contractor selection innovation: Examination of two decades' published research. Construction Innovation, 10(3), 304-328.

Jharkharia, S. \& Shankar, R. (2007). Selection of logistics service provider: An analytic network process (ANP) approach. Omega, 35, 274-289.

Kindström, D., Kowalkowski, C. \& Nordin, F. (2012). Visualizing the value of service-based offeringsEmpirical findings from the manufacturing industry. Journal of Business \& Industrial Marketing, 27(7), $538-546$.

Kugyte, R. \& Sliburyte, L. (2005). A standardized model of service provider selection criteria for different service types: A consumer-oriented approach. Engineering Economics, 3(43), 56-63.

Larsen, T. (2005). Minding your Ps: Three fundamentals for improving business performance. American Institute of Architects (AIA) Practice Management Digest. Retrieved 16 November, 2015, from http://www.aia.org/nwsltr_pm.cfm

Masrom, M. A., \& Skitmore, M. (2010). Sustainability performance of construction: Conceptual models of satisfaction levels in construction projects. In T. Yigitcanlar (Ed.), Rethinking sustainable development: Urban management, engineering, and design (pp. 286-295). Hershey, PA: IGI Global, Engineering Science Reference.

Mathonsi, M. D. \& Thwala, W. D. (2012). Factors influencing the selection of procurement systems in the South African construction industry. African Journal of Business Management, 6(10), 3583-3594.

Mbachu, J. \& Nkedo, R. (2007). Conceptual framework for assessment of client needs and satisfaction in the building development process. Construction Management and Economics, 24(1), 31-44.

Oluwatayo, A. A. (2009). A study of the characteristics of architectural firms in Nigeria (Doctoral dissertation). Department of Architecture, Covenant University, Ota, Nigeria.

Opoko, A. P. (2013). Housing tenure in informal settlements: A case study of Ayobo, Lagos (Doctoral dissertation). Department of Architecture, Covenant University, Ota, Nigeria.

Pearson, M., Egan, N. \& Nakazawa, P. W. (2003). Components of value for a competitive edge. American Institute of Architects (AIA) Practice Management Digest. Retrieved 16 November, 2015, from http://www.aia.org/nwsltr_pm.cfm

Razzouk, N., Seitz, V. \& Webb, J. (2004). What's important in choosing a primary care physician: An analysis of consumer response. International Journal of Health Care Quality Assurance, 17(4), 205-211. 
Rönn, M. (2014). Choosing architects for competitions-Experiences from the selection of design teams in Sweden. FORMakademisk, 7(1), 1-17.

Saaty, T. L. (1980). The analytic hierarchy process. New York, NY: McGraw-Hill.

Scott, D. \& Walt, N. (1995). Choice criteria in the selection of international accounting firms. European Journal of Marketing, 29(1), 27-39.

Sporrong, J. (2011). Criteria in consultant selection: Public procurement of architectural and engineering services. Australasian Journal of Construction Economics and Building, 11(4), 59-76.

Standard Bank (2014) Understanding Africa’s Middle Class. Insights and Strategy. July 2014

Waziri, B. S. \& Bala, K. (2014). Actualizing Nigeria's Vision 20:2020: Imperatives of the construction sector. Civil and Environmental Research, 6(6), 69-75.

Zavadskas, E. K. \& Vilutiene, T. A. (2006). A multiple criteria evaluation of multi-family apartment block's maintenance contractors: I-model for maintenance contractor evaluation and the determination of its selection criteria. Building and Environment, 41(1), 621-632. 